\title{
Czas, który wypadł z ram. Antropocen i ekokrytyczna lektura
} tekstów literackich

\author{
Patryk Szaj
}

\author{
ORCID: 0000-0002-6315-3317
}

these are those things that will have had to have been, that will have had to yet occur ${ }^{1}$. Evelyn Reilly

Jak zatem uprawiać krytykę literacką w czasach potwierdzonego masowego wymierania, tak by nie wydawało się to po prostu absurdalne? Jak dalece takie pisarstwo jest podatne na twierdzenie, że wciąż negujemy antropocen lub negocjujemy z nim, próbując wtłoczyć go w konwencjonalne kategorie? Podstępny efekt antropocenu jako emergentnego fenomenu niosącego radykalnie rewizjonistyczne następstwa polega na tym, że to, co większość ludzi bierze za normalność, musi zmierzać w kierunku formy ekologicznego wyparcia². Timothy Clark

\section{Widmontologia antropocenu}

21 maja 2019 roku Grupa Robocza ds. Antropocenu zarekomendowała oficjalne uznanie nowej epoki geologicznej - za takim werdyktem zagłosowało 29 spośród 33 członków grupy ${ }^{3}$. Niezależnie od tego, czy sam termin wydaje się najfortunniejszy ${ }^{4}$, świadomość, że zakończył się holocen - epoka stabilnego klimatu sprzyjającego rozwojowi cywilizacji ludzkich i życiu, jakie znamy - skłania do zasadniczego przeorientowania zainteresowań badawczych nie tyl-

\footnotetext{
${ }^{1}$ Evelyn Reilly, Apocalypso (New York: Roof Books, 2012), 71.

2 Timothy Clark, Ecocriticism on the Edge. The Anthropocene as a Threshold Concept (London-New York: Bloomsbury, 2015), 48-49.

${ }^{3}$ Zob. „Working Group on the «Anthropocene»”, b.d., http://quaternary.stratigraphy.org/working-groups/ anthropocene/. (dostęp: 11.06.2021)

${ }^{4}$ Zob. Ewa Bińczyk, Epoka człowieka. Retoryka i marazm antropocenu (Warszawa: Wydawnictwo Naukowe PWN, 2018), 77-103.
} 
ko humanistyki środowiskowej ${ }^{5}$, ale i humanistyki jako takiej. Redaktorzy tomu The Anthropocene and the Global Environmental Crisis, Clive Hamilton, Christophe Bonneuil i François Gemenne identyfikują dwa „potężne i przekonujące twierdzenia” wyrażane przez hipotezę antropocenu, których nie mogą zignorować nauki humanistyczne i społeczne: po pierwsze, ludzie stali się siłą telluryczną, przekształcającą funkcjonowanie Ziemi, po drugie, ludzcy (i nie-ludzcy, chciałoby się dodać) mieszkańcy Ziemi w ciągu zaledwie kilku dekad doświadczą globalnej zmiany środowiskowej o bezprecedensowym tempie i skali ${ }^{6}$. Oznacza to nastanie nowego reżimu geologicznego życia na naszej planecie, a w mniejszym - ludzkim - wymiarze także ostateczne podanie w wątpliwość „,nowoczesnej konstytucji” nakazującej traktować społeczeństwo i naturę jako dwa niezależne porządki i ograniczać sprawczość ludzkich działań jedynie do tego pierwszego (a sprawczość aktorów pozaludzkich po prostu ignorować) ${ }^{7}$.

"«The time is out of joint»: czas jest pozbawiony spojeń, zwichnięty, zerwany, porozdzielany, czas jest zepsuty, osaczony i zamroczony, jest rozstrojony, jednocześnie rozregulowany i oszalały. Czas wypadł z ram, zboczył z kursu, biegnie poza samym sobą, niedopasowany do samego siebie" - pisał w 1993 roku Jacques Derrida. Wydaje się, że dziś te niewczesne rozważania tylko zyskały na aktualności. Antropocen jest bowiem czasem katastrofy, ale i katastrofa czasu. Jeśli zgodnie z etymologią katastrophe oznacza „nagły zwrot”, „wywrócenie”, „unieważnienie", katastrofa czasu sprowadza się do zanegowania samej jego linearności: oto okazuje się, że biegnie on w różne strony naraz. Anachronia, zwichnięcie, dis-locatio (czyli, dosłownie, pozbawienie miejsca: zanegowanie fantazmatycznej bliskości tego, co „teraźniejsze”, i tego, co "obecne") dotyczy czasu jako takiego i zamiast spajać go na nowo, powinniśmy raczej radykalnie przemyśleć jego nie-współczesność z samym sobą.

Czyż nie na tym polega doświadczenie antropocenu? Clive Hamilton podkreśla, że termin antropocen nie oznacza po prostu postępujacej eskalacji kryzysu środowiskowo-klimatycznego, ale paradygmatyczną zmianę planetarnych warunków klimatycznych: zerwanie w funkcjonowaniu systemu Ziemi pojętego jako całość. Wielkie przyspieszenie - okres po II wojnie światowej uznawany za jeden z najbardziej wiarygodnych pod względem stratygraficznym momentów początkowych antropocenu ${ }^{9}$ - ontologicznie dzieli więc historię Ziemi na dwie nieprzystające do siebie części ${ }^{10}$. O „zwrocie planetarnym”, czyli głębokiej zmianie relacji pomiędzy ludzkością a resztą aktorów tego świata, piszą także autorzy jednego z najczęściej cytowanych artykułów na temat antropocenu, The Anthropocene: Are Humans Now Overwhelming the Great Forces of

${ }^{5}$ Zob. np. Environmental Humanities: Voices from the Anthropocene, red. Serpil Oppermann i Serenella Iovino (LondonNew York: Rowman and Littlefield, 2017); por. też Clive Hamilton, „A New Anthropocentrism”, w Defiant Earth: The Fate of Humans in the Anthropocene (Crows Nest: Allen\&Unwin, 2017), który stwierdza, że antropocen skłania raczej do wypracowania „nowego antropocentryzmu”, niż do rozwijania tendencji posthumanistycznych.

${ }^{6}$ Clive Hamilton, Christophe Bonneuil i François Gemenne, „Thinking the Anthropocene”, w The Anthropocene and the Global Environmental Crisis: Rethinking Modernity in a New Epoch, red. Clive Hamilton, Christophe Bonneuil i François Gemenne (New York: Routledge, 2015), 3-4.

${ }^{7}$ Zob. Bruno Latour, Nigdy nie byliśmy nowocześni. Studium z antropologii symetrycznej, tłum. Maciej Gdula (Warszawa: Oficyna Naukowa, 2011).

${ }^{8}$ Jacques Derrida, Widma Marksa. Stan długu, praca żałoby i nowa międzynarodówka, tłum. Tomasz Załuski (Warszawa: Wydawnictwo Naukowe PWN, 2016), 42.

${ }^{9}$ Zob. np. Will Steffen i in., „The Trajectory of the Anthropocene: The Great Acceleration”, Anthropocene Review, 2015. Instruktywne są zwłaszcza zamieszczone w artykule tabele wyraźnie wskazujące na wykładniczy wzrost rozmaitych trendów socjoekonomicznych i trendów systemu Ziemi po 1950 roku.

${ }^{10}$ Clive Hamilton, Defiant Earth. The Fate of the Humans in the Anthropocene (Crows Nest: Allen\&Unwin, 2017). 
Nature?, Will Steffen, Paul Crutzen i John McNeill, których zdaniem działania ludzkości nieuchronnie popychają Ziemię w stronę „planetarnej terra incognita” ${ }^{11}$. Rzecz nie w tym, że kumulatywne efekty antropopresji są coraz bardziej dojmujące, ale w tym, że skutkują one kompletną nieprzewidywalnością tego, co wydarzy się z systemem Ziemi w ciągu najbliższych dekad. Podobnie myśli nawet jeden z krytyków terminu „antropocen” Jason W. Moore, który z kolei stwierdza, że „Ludzkość - a wraz z nią reszta życia - znalazła się na progu czegoś, co przedstawiciele nauki o systemie Ziemi nazywają «zwrotem systemowym»"12. Wreszcie Tobias Boes i Kate Marshall zauważają, że podstawową przesłanką wszystkich teorii antropocenu jest przekonanie o absolutnym zerwaniu z przeszłością i o nieodwracalnej zmianie kondycji ludzkiej ${ }^{13}$.

Można zatem powiedzieć, że nastanie antropocenu stanowi ironiczny punkt dojścia nowoczesności. Niezależnie od tego, czy nigdy nie byliśmy nowocześni (jak uważa Bruno Latour ${ }^{14}$ ), czy też choć na chwilę udało nam się uzyskać ten status (stanowisko Timothy'ego Mortona ${ }^{15}$ ), z pewnością już nigdy nowocześni nie będziemy: linearny bieg ludzkiej historii został załamany przez głęboki czas geologiczny. Ziemia na powrót stała się pełnoprawnym aktorem, za którego sprawą - jak stwierdza Latour - nastąpiła „zaskakująca inwersja tła i pierwszego planu”, tak że teraz "to ludzka historia zastygła w bezruchu, a historia naturalna nabiera szalonego tempa"16.

Dodajmy, że klimatolodzy od dawna podkreślają, że zmiany klimatu mają charakter nieliniowy, co oznacza, że nie są one wprost proporcjonalne do wyjściowych warunków klimatycznych. Dzieje się tak ze względu na występowanie ujemnych i dodatnich sprzężeń zwrotnych, czyli odpowiedzi systemu klimatycznego osłabiających lub wzmacniających efekt naruszających stan równowagi wymuszeń. W antropocenie działają przede wszystkim sprzężenia dodatnie, antropopresja zaburza bowiem szybki cykl węglowy ${ }^{17}$, a w konsekwencji wpływa także na wolny cykl węglowy, czyli „procesy wymiany węgla, których skala czasowa jest długa («geologiczna»), rzędu tysięcy i setek tysięcy lat"18, i które pełnią funkcję swoistego termostatu Ziemi. Co istotne, sprzężenia zwrotne różnią się tempem działania - niektóre operują w geologicznej skali tysięcy lat, inne w ludzkiej skali kilku lat, a nawet tygodni, przy czym co do zasady sprzężenia dodatnie dają o sobie znać szybciej niż ujemne ${ }^{19}$.

\footnotetext{
${ }^{11}$ Paul Crutzen, Will Steffen i John R. McNeill, „The Anthropocene: Are Humans Now Overwhelming the Great Forces of Nature?", Ambio 8, nr 36 (2007): 614.

${ }^{12}$ Jason W. Moore, „Introduction: Anthropocene or Capitalocene? Nature, History, and the Crisis of Capitalism”, w Anthropocene or Capitalocene? Nature, History, and the Crisis of Capitalism, red. Jason W. Moore (Oakland: PM Press, 2016), 1.

${ }^{13}$ Tobias Boes i Kate Marshall, „Writing the Anthropocene: An Introduction”, The Minnesota Review, nr 83 (2014): 62. Por. też Dipesh Chakrabarty, „The Human Condition in the Anthropocene”, The Tanner Lectures in Human Values, 2015.

${ }^{14}$ Latour, Nigdy nie byliśmy nowocześni. Studium z antropologii symetrycznej.

${ }^{15}$ Timothy Morton, Hyperobjects: Philosophy and Ecology After the End of the World (Minneapolis-London: University of Minnesota Press, 2013), 1-24.

${ }^{16}$ Bruno Latour, „Agency at the time of the Anthropocene”, New Literary History 45, nr 1 (2014): 13.

${ }^{17} Z$ ob. np. Crutzen, Steffen i McNeill, „The Anthropocene: Are Humans Now Overwhelming the Great Forces of Nature?”; Justin McBrien, „Accumulating Extinction: Planetary Catastrophism in the Necrocene”, w Anthropocene or Capitalocene? Nature, History, and the Crisis of Capitalism, red. Jason W. Moore (Oakland: PM Press, 2016), 116-37.

${ }^{18}$ Klimatyczne $A B C$, red. Magdalena Budziszewska, Aleksandra Kardaś i Zbigniew Bohdanowicz (Warszawa: Wydawnictwa Uniwersytetu Warszawskiego, 2021), 39.

${ }^{19}$ Zob. Klimatyczne $A B C, 186-92$.
} 
Innym pojęciem z zakresu klimatologii wskazującym na nieliniowość zmian klimatu jest koncepcja planetarnych punktów krytycznych, czyli progowych wartości danych parametrów (np. temperatury), po przekroczeniu których uruchamia się kaskada zdarzeń obejmujących cały system klimatyczny, tak że w konsekwencji zaczyna on dążyć do innego stanu równowagi ${ }^{20}$. Przekroczenie punktów krytycznych jest więc nieodwracalne (w ludzkich skalach czasowych). Co więcej, „komunikaty” wysyłane przez system planetarny są, by tak rzec, niewczesne: dowiadujemy się o przekroczeniu punktu krytycznego dopiero wtedy, gdy nie da się już powstrzymać wywołanych przez nie skutków ${ }^{21}$.

W nauce o systemie Ziemi funkcjonuje również zaproponowana w 2009 roku przez Johana Rockströma i jego współpracowników koncepcja dziewięciu granic planetarnych, których przekroczenie spowodować może nieliniową i nagłą zmianę środowiskową. Trzy z nich - zmiana klimatu, zaburzenie cyklu azotowego i fosforowego oraz spadek bioróżnorodności - już zostały przekroczone. Trzy kolejne - zakwaszenie oceanów, wyczerpanie zasobów słodkiej wody oraz zmiana systemów lądowych (związana $z$ deforestacją i rozwojem rolnictwa) - znajdują się niepokojąco blisko progu krytycznego ${ }^{22}$. Wszystkie te przeobrażenia mają charakter nieodwracalny, dlatego redaktorzy tomu The Anthropocene and the Global Environmental Crisis nie wahają się stwierdzić, że system Ziemi już teraz wkroczył w „inną [niż w holocenie - P.S.] trajektorię”, po której porusza się z „olbrzymim pędem”23.

Autorzy podręcznika Klimatyczne $A B C$ posługują się obrazowym kontrastem, który uzmysławia, że w kategoriach geologicznych ów pęd jest naprawdę olbrzymi: „wyjście Ziemi z ostatniej epoki lodowej oznaczało wzrost średniej temperatury o 3-3,5 stopnia w ciągu ok. 8 tysięcy lat, co dawało funkcjonującym na Ziemi gatunkom dużo więcej czasu na migrację itp. Obecnie musimy liczyć się z taką zmianą w ciągu 100-200 lat"24. Warto przytoczyć w tym kontekście równie obrazowe słowa Timothy'ego Mortona:

Czytam, że 75\% efektów globalnego ocieplenia utrzyma się przez najbliższe 500 lat. Próbuję sobie wyobrazić, jak wyglądało życie w 1513 roku. W ciągu 30000 lat prądy oceaniczne pochłoną większość związków węgla, ale $25 \%$ nadal będzie wisieć w atmosferze. Czas połowicznego rozpadu izotopu 239 plutonu to 24100 lat. Okresy te są tak długie, jak cała dotychczasowa widzialna historia człowieka. [...] 7\% efektów globalnego ocieplenia wciąż będzie występować za 100000 lat, dopóki skały magmowe $z$ wolna nie pochłoną ostatnich gazów cieplarnianych. Zdecydowałem się określić te skale czasowe jako wstrzq̨ające, zatrważajq̨ce i petryfikujące ${ }^{25}$.

${ }^{20}$ Zob. Klimatyczne $A B C$, 32-35.

${ }^{21}$ Tak jest np. z ekosystemem Grenlandii, co w 2020 roku ogłosili Michaela King i jej współpracownicy. Oznacza to, że lód Grenlandii nie przestanie topnieć, nawet jeśli wstrzymamy wszystkie emisje gazów cieplarnianych: rokrocznie ubywa go więcej, niż przybywa zasilającego go śniegu. Michalea D. King i in., „Dynamic ice loss from the Greenland Ice Sheet driven by sustained glacier retreat", Communications Earth \& Environment 1, nr 1 (2020). Nieunikniony jest już także rozpad lądolodu Antarktydy Zachodniej. Marcin Popkiewicz i Szymon Malinowski, „Rozpad lądolodu Antarktydy Zachodniej nieunikniony”, Nauka o klimacie, 2015, https:// naukaoklimacie.pl/aktualnosci/rozpad-ladolodu-antarktydy-zachodniej-nieunikniony-77. (dostęp: 11.06.2021)

${ }^{22}$ Zob. Johan Rockström i in., „Planetary Boundaries: Exploring the Safe Operating Space for Humanity”, Ecology and Society 14, nr 2 (2009).

${ }^{23}$ Hamilton, Bonneuil i Gemenne, „Thinking the Anthropocene”, 11.

${ }^{24}$ Klimatyczne $A B C, 96$.

${ }^{25}$ Morton, Hyperobjects: Philosophy and Ecology After the End of the World, 58-59. Ostatni przymiotnik - petrifying - jest dla Mortona szczególnie istotny, czyni on bowiem aluzję do tego, że również ciała ludzkie na przestrzeni głębokiego czasu geologicznego przekształcą się w skamieliny. 
Żyjemy więc w co najmniej w dwóch czasach naraz: w „zwykłej” historii ludzkiej i w toczącej się (pozornie) obok nas geohistorii ${ }^{26}$. Głęboka przyszłość geologiczna już tu jest. Paradoksalnie, przyszłość ta pochodzi z przeszłości - z każdej tony CO2 (lub jej ekwiwalentu w postaci innych gazów cieplarnianych) emitowanej do atmosfery od XVIII wieku. Słowami Derridy: „[...] coś, co wydaje się przed nami, przyszłość, z góry powraca: z przeszłości, z tego, co jest za nami”27.

Jeśli jednak widmontologia ${ }^{28}$ pomaga zrozumieć, że czas wypadł z ram, udziela ona jeszcze jednej lekcji: lekcji sprzeciwu wobec logiki apokaliptycznej. Koniec świata (jaki znamy ${ }^{29}$ ) to nie koniec świata (w ogóle): widma, które nas nawiedzają, pochodzą zarówno z przeszłości, jak i z przyszłości (to, co „nadejdzie w nadchodzącej przyszłości [l’à-venir]”30: mesjaniczna obietnica dla wszystkich ludzi... i, co widmowo zapowiadały kolejne prace Derridy ${ }^{31}$, nie-ludzi, albo też monstrualne nowe formy kategoryzacji, domestykacji i kolonizacji). Dlatego antropocen to nie tylko czas kryzysowy, to także czas kairotyczny: zwrotny moment, punkt krytyczny, właściwa pora wskazująca na pilność wyzwań i konieczność ostatecznej, rozstrzygającej decyzji, od której zależy dalszy los nie tylko ludzkości, ale wszystkich aktorów tego świata. Na ten aspekt wskazuje Michael Northcott, który stwierdza, że nie możemy już dłużej pojmować czasu w kategoriach chronos (,sukcesywne cykliczne przemijanie dni i nocy, chwila po chwili, pokolenie po pokoleniu”), ale właśnie w kategoriach kairos („zwiastun wielkiej lub nagłej zmiany albo potrzeby zmiany”32). Słowami Derridy: „W doświadczeniu końca, w jego nadejściu, nieustępliwym, natychmiastowym, zawsze nieuchronnie eschatologicznym, w krańcowej krańcowości dnia dzisiejszego zapowiada się [...] przyszłość tego, co nadchodzi”33.

$\mathrm{Z}$ tej perspektywy bardzo ciekawie prezentuje się reinterpretacja pojęcia antropocen dokonana przez Boesa i Marshall, którzy wskazują na fakt, że nazwy trzech poprzednich epok geologicznych - pliocenu, plejstocenu i holocenu - oznaczają, kolejno, „nowy czas”, „nowszy czas” i „całkowicie nowy czas”. W związku z tym antropocen da się rozumieć nie tyle jako

\footnotetext{
${ }^{26}$ Por. Dipesh Chakrabarty, „Klimat historii. Cztery tezy”, tłum. Magda Szcześniak, Teksty Drugie 5 (2014): 168-99.

${ }^{27}$ Derrida, Widma Marksa. Stan długu, praca żałoby i nowa międzynarodówka, 30.

${ }^{28} \mathrm{Nt}$. widmontologii zob. np. Jakub Momro, Widmontologie nowoczesności. Genezy (Warszawa: Wydawnictwo IBL PAN, 2014); Andrzej Marzec, Widmontologia. Teoria filozoficzna i praktyka artystyczna ponowoczesności (Warszawa: Fundacja Bęc Zmiana, 2015); Widma Derridy, red. Agata Bielik-Robson i Piotr Sadzik (Warszawa: Wydawnictwo IBL PAN, 2018). Nt. wykorzystania myśli Derridy w konceptualizacji problemów antropocenu zob. np. numer tematyczny Deconstruction in the Anthropocene czasopisma Oxford Literary Review 34, nr 2 (2012); Mark Fisher, Ghosts of My Life: Writings on Depression, Hauntology and Lost Futures (Alresford: Zero Books, 2014); Boes i Marshall, „Writing the Anthropocene: An Introduction”.

${ }^{29}$ Zob. Immanuel Wallerstein, Koniec świata jaki znamy, tłum. Michał Bilewicz, Adam W. Jelonek i Krzysztof Tyszka (Warszawa: Wydawnictwo Scholar, 2004); Claus Leggewie i Harald Welzer, Koniec świata, jaki znaliśmy. Klimat, przyszłość i szanse demokracji, tłum. Piotr Buras (Warszawa: Krytyka Polityczna, 2012).

${ }^{30}$ Derrida, Widma Marksa. Stan długu, praca żałoby i nowa międzynarodówka, 14.

${ }^{31}$ Zob. Jacques Derrida, L’Animal que donc je suis (Paris: Galilée, 2006); Jacques Derrida, Séminaire La bête et le souverain, t. 1 (Paris: Galilée, 2008); Jacques Derrida, Séminaire La bête et le souverain, t. 2 (Paris: Galilée, 2010).

${ }^{32}$ Michael Northcott, „Eschatology in the Anthropocene: From the Chronos of Deep Time to the Kairos of the Age of Humans", w The Anthropocene and the Global Environmental Crisis: Rethinking Modernity in a New Epoch, red. Clive Hamilton, Christophe Bonneuil i François Gemenne (London-New York: Routledge, 2015), 107.

${ }^{33}$ Derrida, Widma Marksa. Stan długu, praca żałoby i nowa międzynarodówka, 70-71. Jest to szczególnie istotne np. dla ekokrytyki postkolonialnej skupionej na zagadnieniach sprawiedliwości środowiskowej i (ludzkich oraz pozaludzkich) migracji klimatycznych. Zob. np. Andrew Baldwin, „Postcolonial Futures: Climate, Race, and the Yet-to-Come”, ISLE Interdisciplinary Studies in Literature and Environment 24, nr 2 (2017); Serpil Oppermann, „Introducing Migrant Ecologies in an (Un)bordered World”, ISLE Interdisciplinary Studies in Literature and Environment 24, nr 2 (2017).
} 
„epokę człowieka” (wraz z całym zawartym w niej antropocentryzmem i ludzkim ekscepcjonalizmem), ile jako „czas nowego człowieka”, anthropos kainos ${ }^{34}$, człowieka więcej-niż-ludzkiego, sympojetycznego ${ }^{35}$, stowarzyszonego $\mathrm{z}$ innymi aktorami tego świata.

W podobnym kierunku zmierza refleksja Mortona. Autor książki Ecology without Nature stawia prowokacyjną tezę, że koniec świata już się wydarzył. Amerykański literaturoznawca ma na myśli fenomenologiczny koncept świata, który wraz z nadejściem hiperobiektów - wytworów antropocenu wymykających się ludzkiemu rozumieniu i kontroli, wykraczających poza ludzkie skale czasoprzestrzenne ${ }^{36}$ - stał się nieoperatywny. „Świat” był bowiem czymś, co jak głosi dobrze znana lekcja Martina Heideggera ${ }^{37}$ - „miał” jedynie człowiek, podczas gdy inni aktorzy byli albo weń „ubodzy” (jak zwierzęta), albo całkowicie go pozbawieni (jak tzw. materia nieożywiona). Ten „świat” zdaniem Mortona nie tylko się skończył, ale tak naprawdę nigdy nie istniał. Z perspektywy realizmu spekulatywnego i ontologii zorientowanej na przedmiot „Istoty ludzkie nie mają świata z bardzo dobrego powodu: ponieważ żadna istota nie ma świata" ${ }^{38}$. Zamiast „świata” istnieje natomiast bliskość, złączenie, wymieszanie, splątanie, „szereg unikalnych bytów (rolnicy, psy, irysy, ołówki, LED-y), którym jestem winien zobowiązanie z tego prostego faktu, że egzystencja jest koegzystencją. Nie muszę sprawdzać swojej listy kontrolnej światowania, by upewnić się, że nie-człowiek, o którym mowa, liczy się jako coś, o co mógłbym się troszczyć"39.

Koniec świata nastąpił jednak z jeszcze jednego, nie mniej ważnego powodu. Odwołując się do ustaleń fizyki kwantowej, Morton udowadnia, że linearny koncept czasu jest fenomenem czysto estetycznym. Czas okazuje się raczej po derridiańsku sfałdowany: nie pełni funkcji „tła”, na którym wydarza się istnienie rzeczy, odwrotnie - każda rzecz istnieje we własnej temporalności, a różne temporalności nieustannie na siebie zachodzą. Hiperobiekty, czyli „byty, które są ogromnie rozciągnięte w czasie, wywierają biegnącą w dół presję przyczynową na byty krótkotrwałe. Jednym z jaskrawych efektów globalnego ocieplenia jest więc fenologiczna asynchronia: fakt niezsynchronizowania wydarzeń życiowych roślin i zwierząt" ${ }^{40}$. Stąd właśnie wstrząsające, zatrważające i petryfikujące skale czasowe antropocenu. Gdy patrzę na ropę naftową, spoglądam w przeszłość Ziemi. Gdy spalam paliwa kopalne, przyszłość drąży moją teraźniejszość. Dlatego koniec świata nie jest nagłym, apokaliptycznym wydarzeniem, ale czymś, co rozciąga się na głęboki czas geologiczny. Oto, jak pisze Morton, „widmowa” rzeczywistość antropocenu ${ }^{41}$.

\footnotetext{
${ }^{34}$ Boes i Marshall, „Writing the Anthropocene: An Introduction”, 61.

${ }^{35} \mathrm{Nt}$. sympojesis zob. Donna J. Haraway, „Staying with the Trouble: Anthropocene, Capitalocene, Chthulucene”, w Anthropocene or Capitalocene? Nature, History, and the Crisis of Capitalism, red. Jason W. Moore (Oakland: PM Press, 2016).

${ }^{36}$ Nt. hiperobiektów zob. też Anna Barcz, „Przedmioty ekozagłady. Spekulatywna teoria hiperobiektów Timothy'ego Mortona i jej (możliwe) ślady w literaturze”, Teksty Drugie 2 (2018): 75-87.

${ }^{37}$ Martin Heidegger, Die Grundbegriffe der Metaphysik. Welt-Endlichkeit-Einsamkeit (Frankfurt am Main: Vittorio Klostermann, 1983).

${ }^{38}$ Morton, Hyperobjects: Philosophy and Ecology After the End of the World, 108.

${ }^{39}$ Morton, 125.

${ }^{40}$ Morton, 67.

${ }^{41}$ Morton, 194.
} 


\section{Ekokrytyka w czasach antropocenu}

Jak zatem uprawiać literaturoznawstwo w czasach planetarnego kryzysu środowiskowo-klimatycznego? Czy nauka o literaturze niezainteresowana paradygmatyczną zmianą antropocenu nie wydaje się anachroniczna - już nie w widmontologicznym, ale w aksjologicznym sensie: nieodpowiadająca na wyzwania współczesności? Czy antropocentryczne tryby lekturowe nie stanowią uchylania się od intelektualnej i etycznej odpowiedzialności? Wreszcie: czy dyskurs antropocenu nie stawia także poważnych wyzwań dotychczasowej ekokrytyce?

Jednym z badaczy, którzy starają się udzielić odpowiedzi na te pytania, jest Timothy Clark. Traktuje on antropocen jako „koncept progowy”, podający w wątpliwość podstawowy dogmat ekokrytyki, który zwięźle wyrażają często cytowane słowa Lawrence’a Buella, że „kryzys ekologiczny jest także kryzysem wyobraźni”42, oraz pytania w rodzaju „czy poezja może zbawić Ziemię?”, „czy akt pisania i uważnego czytania może zbawić planetę?”33. Zbyt wiele ekokrytyczek i ekokrytyków padło zdaniem Clarka ofiarą iluzji, że problemy środowiskowe da się rozwiązać za pomocą środków kulturowych, tymczasem „Wyolbrzymianie znaczenia tego, co wyobraźniowe, samo w sobie wiąże się z ryzykiem umacniania czegoś w rodzaju odwracających uwagę spraw drugoplanowych [diversionary side-show], ślepych na swą relatywną nieistotność" ${ }^{44} \mathrm{w}$ porównaniu $\mathrm{z}$ siłą materialnych sposobów produkcji, nawykami żywieniowymi, zużyciem energii, trendami reprodukcyjnymi itp. Wprawdzie tego typu świadomość istniała w ekokrytyce od dawna - np. Kate Rigby już w 2002 roku podkreślała, że „ważne jest, aby rozpoznać wpływ struktur społecznych, politycznych i ekonomicznych na utrwalanie, transformację lub przemieszczanie obrazów natury przekazywanych przez teksty kultury" ${ }^{\prime 4}$, także rosnąca świadomość metodologiczna ekokrytyki związana z ewolucją od I do IV falii ${ }^{46}$ polegała na identyfikacji własnych słabości - niemniej zdaniem Clarka przekroczenie progu antropocenu całkowicie zmieniło reguły gry:

Antropocen nazywa nowo rozpoznany kontekst, który pociąga za sobą uczące pokory uznanie ograniczeń reprezentacji kulturowej jako siły zdolnej do zmiany stosunków międzyludzkich w porównaniu z licznymi czynnikami ekonomicznymi, meteorologicznymi, geograficznymi i mikrobiologicznymi oraz dynamiką populacji, a także efektami skali, takimi jak prawo wielkich liczb, które wynikają z próby myślenia na skalę planetarną ${ }^{47}$.

\footnotetext{
${ }^{42}$ Lawrence Buell, The Environmental Imagination: Thoreau, Nature Writing, and the Formation of American Culture (Cambridge-London: Harvard University Press, 1995), 2. W wywiadzie z W.S. Merwinem przeprowadzonym przez Julię Fiedorczuk padają jeszcze mocniejsze słowa: „tylko wyobraźnia może nas uratować”. William Stanley Merwin i Julia Fiedorczuk, „Już tylko o ogrodach”, Tygodnik Powszechny, 2013, https://www. tygodnikpowszechny.pl/juz-tylko-o-ogrodach-19688. (11.06.2021)

${ }^{43}$ Zob. John Felstiner, Can Poetry Save the Earth? A Field Guide to Nature Poems (New Haven: Yale University Press, 2009); Ken Hiltner, „General Introduction”, w Ecocriticism. The Essential Reader, red. Ken Hiltner (London-New York: Routledge, 2015) (drugi cytat za: Aleksandra Ubertowska, „«Mówić w imieniu biotycznej wspólnoty». Anatomie i teorie tekstu środowiskowego", Teksty Drugie, nr 2 (2018): 18).

${ }^{44}$ Clark, Ecocriticism on the Edge. The Anthropocene as a Threshold Concept, 21.

${ }^{45}$ Kate Rigby, „Ecocriticism”, w Introducing Criticism at the 21st Century, red. Julian Wolfreys (Edinburgh: Edinburgh University Press, 2002), 157. Por. też podrozdział „Reconnecting the Social and the Ecological” $\mathrm{z}$ tego tekstu.

${ }^{46}$ Zob. np. Ubertowska, „ «Mówić w imieniu biotycznej wspólnoty». Anatomie i teorie tekstu środowiskowego”.

${ }^{47}$ Clark, Ecocriticism on the Edge. The Anthropocene as a Threshold Concept, 21.
} 
Właśnie efekty skali stają się głównym obiektem namysłu angielskiego literaturoznawcy. Punktem wyjścia Clarka jest odwołanie do przedstawionej przez Bradena R. Allenby'ego i Daniela Sarewitza koncepcji trzech poziomów skomplikowania relacji gatunku ludzkiego względem technologii ${ }^{48}$. Poziom I polega na instrumentalnym traktowaniu technologii jako prostego narzędzia. Na II poziomie skomplikowania narzędzie to zostaje wciągnięte w socjotechniczne systemy złożone, które są mniej przewidywalne i bardziej skomplikowane. Na poziomie III komplikacje i nieprzewidywalność mają jeszcze dalej posunięte implikacje - jest to poziom radykalnej kontyngencji, który Clark porównuje z Mortonowskimi hiperobiektami ze względu na to, że wymyka się on naszym zdolnościom modelowania, przewidywania, a nawet rozumienia.

Podczas gdy w tradycyjnych modelach kulturowych, politycznych, ekologicznych - a także $\mathrm{w}$ tradycyjnym literaturoznawstwie - dominują interpretacje związane z I i II poziomem skomplikowania, „coraz więcej wydarzeń i problemów antropocenu wyłania się na poziomie III, czyniąc sposoby myślenia ograniczone do poziomu I i II przestarzałymi, nawet jeśli poziomy te wciąż opisują rodzaje myślenia, którymi próbuje się kierować większość ludzi”"49. Jak to ujmują Allenby i Sarewitz, „jeśli to rozumiesz, nie jest to prawdą; a jeśli jest to prawdą, nie możesz tego zrozumieć" 50 .

Na pierwszy plan w refleksji Clarka wysuwają się wielowymiarowe sprzeczności pomiędzy skalą ludzką i skalą planetarną. Autor Ecocriticism on the Edge ustanawia „terestrialność” jako normę, którą - podobnie jak Morton - przeciwstawia „światu”. Chodzi przede wszystkim o konieczność rozciągnięcia „zwykłych” skal czasowych i przestrzennych, w jakich na co dzień sytuujemy swoje działania poznawcze, kulturotwórcze, polityczne itd., a także tradycyjne literaturoznawstwo. Terestrialność staje się tu konceptem granicznym wyrażającym nieuchwytność olbrzymich skal czasoprzestrzennych antropocenu oraz fałsz zdroworozsądkowych ujęć „świata życia”, a jednocześnie sprawczość Ziemi jako (groźnego i suwerennego, jak powiedziałby Latour ${ }^{51}$ ) aktora. Co istotne, nieintuicyjność tego rozciągnięcia wynika nie tylko z przyzwyczajeń kulturowych, ale z głębszych ewolucyjnych uwarunkowań gatunku Homo sapiens. Ewolucyjnie jesteśmy bowiem przystosowani do reagowania na zagrożenia nagłe i bezpośrednie, a nie długofalowe i abstrakcyjne. Rzecz w tym, że antropocen ujawnia coś w rodzaju ironicznego „podwójnego uwiązania” pomiędzy biologicznymi ograniczeniami ludzkiej percepcji a tym, jak bardzo percepcja ta jest niedostosowana do dokonującego się zerwania:

Rozumiemy odległość, wysokość i szerokość w kategoriach wymiarowości danej nam wraz z naszą ucieleśnioną egzystencją. [...] Nie jest to kwestia czysto kulturowa, podatna na zmiany za pomocą środków kulturowych, ale określony, nieunikniony sposób odczytywania rzeczy [...]. Antropocen wiąże się z uświadomieniem, jak głęboko myląca może być ta skala ${ }^{52}$.

\footnotetext{
${ }^{48}$ Zob. Braden R. Allenby i Daniel Sarewitz, The Techno-Human Condition (MIT Press, 2018).

${ }^{49}$ Clark, Ecocriticism on the Edge. The Anthropocene as a Threshold Concept, 9.

${ }^{50}$ Allenby i Sarewitz, The Techno-Human Condition, 186.

${ }^{51}$ Latour, „Agency at the time of the Anthropocene”, 6.

${ }^{52}$ Clark, Ecocriticism on the Edge. The Anthropocene as a Threshold Concept, 30.
} 
Każe to spojrzeć krytycznie również na wiele wglądów formułowanych przez nowsze nurty ekokrytyki. Clark pozostaje sceptyczny np. wobec ekokrytyki materialnej oraz koncepcji „ucieleśnionego osadzenia" (embodied embeddedness), które z jednej strony starają się przywrócić związek pomiędzy człowiekiem a resztą materii (zwracając też uwagę na sprawczość samej materii) ${ }^{53}$, z drugiej jednak cechują się „transcendentalną głupotą" ${ }^{54}$ polegającą na ograniczaniu się do najbliższego „świata życia”: aktorów, z którymi jesteśmy bezpośrednio usieciowieni. Podobnie jak Morton, Clark uważa, że tak rozumiany świat jest w najlepszym razie epifenomenem, w najgorszym zaś - fantazmatem zakrywającym nieuchwytność, intelektualną trudność i nieintuicyjną naturę codziennego życia w antropocenie. Analogicznie ujmuje tę kwestię Latour: „sprawy stały się tak pilne i gwałtowne, że do pewnego stopnia pokojowy projekt kontraktu między stronami wydaje się nieosiągalny. Nieskończenie bardziej prawdopodobna niż kontrakt jest wojna. [...] Słowa takie jak symbioza, harmonia, ugoda, porozumienie, te ideały ekologii głębokiej, trącą wcześniejszym, mniej pogrążonym w mrokach niewiedzy czasem. Od tamtej pory wszystko zmieniło się na gorsze" ${ }^{\text {. }}$.

Te ostatnie cechy wiążą się z „emergentnym” statusem antropocenu jako wydarzenia, którego nowość nie znajduje żadnego adekwatnego dyskursu: „Antropocen pod każdym względem może być nazwany efektem radykalnej i nieprzewidywalnej emergencji w kondycji świata, proliferacji sytuacji na III poziomie skomplikowania" ${ }^{56}$. Właśnie ta emergencja decyduje o wpisanej w kondycję antropocenu anachronii: nasze paradygmaty poznawcze, etyczne, polityczne, społeczne itp. okazują się głęboko niewczesne względem wyzwań, przed którymi stoimy. Dotyczy to także dotychczasowych norm lekturowych i przekonań na temat warunków, jakie musi spełniać wiarygodna interpretacja tekstów literackich:

Poznawcze i etyczne postulaty antropocenu podkreślają, jak głęboko pełne „rozumienie” tekstu nie polega na ponownym umieszczeniu go jedynie w kulturowym kontekście czasu jego powstania. Tekst z niego wyskakuje, trwa, i może mieć nieprzewidziane konsekwencje ${ }^{57}$.

Interpretacja jako rodzaj działania scalającego sensy tekstu literackiego pozostaje w sprzeczności z lekcją antropocenu - czytanie nie może polegać po prostu na harmonijnym akcie „odzyskania”, antropocen wymaga, aby stało się ono także „miarą nieodwracalnego załamania świadomości i rozumienia, emergentnej nieczytelności" ${ }^{38}$. Wynika stąd postulat lektury biorącej pod uwagę kumulatywne efekty skali, które sprawiają, że „na pewnym nieokreślonym progu liczne działania ludzkie, same w sobie nieistotne (ogrzewanie domu, wycinka drzew, latanie pomiędzy kontynentami, gospodarka leśna), tworzą nowe, niedające się zmierzyć zdarzenie fizyczne, zmieniające podstawowe cykle ekologiczne planety" ${ }^{59}$. Interpretowanie tekstów literackich z tą świadomością oznacza wdrożenie lektury wielko- i wieloskalowej,

\footnotetext{
${ }^{53}$ Zob. np. Material Ecocriticism, red. Serenella Iovino i Serpil Oppermann (Bloomington: Indiana University Press, 2014).

${ }^{54}$ Clark, Ecocriticism on the Edge. The Anthropocene as a Threshold Concept, 38.

${ }^{55}$ Latour, „Agency at the time of the Anthropocene”, 6.

${ }^{56}$ Clark, Ecocriticism on the Edge. The Anthropocene as a Threshold Concept, 47.

${ }^{57}$ Clark, 65 .

${ }^{58} \mathrm{Clark}, 62$.

${ }^{59}$ Clark, 72.
} 
i to mimo że rozbieżne efekty skali są nieprzedstawialne, wymykając się tradycyjnym fabułom ograniczonym do dramatów międzyludzkich, a nawet inwencyjnym modelom zoo- czy ekopoetyki ${ }^{60}$. Clark proponuje rozróżnienie trzech skal interpretacyjnych: pierwsza związana jest z przeżyciami indywidualnego bohatera bądź bohaterów tekstu, druga - najczęściej przyjmowana w studiach literaturoznawczych - rozciąga się w przestrzeni na kulturę narodową i jej reprezentantów, natomiast w czasie na pewien „okres historyczny” istotny dla przesłania utworu. W kontekście antropocenu najważniejsza, a jednocześnie najtrudniejsza do wyobrażenia, jest skala trzecia: ta, w której efekty skali się kumulują i zaczynają z wolna przesłaniać konwencjonalne odczytania. Temporalnie może się ona rozciągać co najmniej na kilka stuleci, zaś przestrzennie - na całą Ziemię. Jest to też skala przyjmująca zdehumanizowane spojrzenie na ludzkie działania.

Spójrzmy dla przykładu na wiersz Julii Fiedorczuk z tomu Tlen pod tytułem Płynie Wisła, ptynie:

$$
\begin{aligned}
& \text { po polskiej krainie } \\
& \text { jeśli coś w niej żyje } \\
& \text { to niedługo zginie }{ }^{61}
\end{aligned}
$$

Pierwsza skala jest tu właściwie nieistotna - liryka pośrednia wskazuje na ponadjednostkową refleksję, która momentalnie odnosi się do skali drugiej: zarówno w treści, jak i w formie wiersz czyni aluzję do pieśni patriotycznej Edmunda Wasilewskiego wraz z charakterystycznym dla niej synkopowym rytmem krakowiaka (przestawka w pierwszym wersie utrzymująca trocheiczny tok utworu). Po co jednak tekst wspiera się na tym intertekstualnym nawiązaniu? Odpowiadając na to pytanie, uruchamiam skalę trzecią: zaczynam zastanawiać się nad takimi zagadnieniami, jak zanieczyszczenie wód gruntowych efektami ubocznymi przemysłowej produkcji mięsa, eutrofizacja gleb związana ze stosowaniem nawozów azotowo-fosforowych (jedna $z$ trzech przekroczonych granic planetarnych), antropogeniczna utrata bioróżnorodności (druga z trzech przekroczonych granic planetarnych) czy wreszcie stepowienie ziem Polski i coraz bardziej uciążliwe susze (rokrocznie ogłaszane „rekordowo niskie" poziomy Wisły).

Tak naprawdę jednak wiersz Fiedorczuk jest dla rozważań Clarka niereprezentatywny. Angielskiemu literaturoznawcy chodzi o uwzględnienie w praktyce ekokrytycznej także takich tekstów, które nie mieściły się w obszarze zainteresowań tradycyjnej ekokrytyki (np. nie odpowiadały definicji „tekstu środowiskowego” Lawrence’a Buella ${ }^{62}$, choć trzeba pamiętać, że już ekokrytyka II fali postulowała czytanie utworów niemówiących explicite o „naturze”,

\footnotetext{
${ }^{60}$ Zob. np. Kate Rigby, „Earth, World, Text: On the (Im)possibility of Ecopoiesis”, New Literary History 35, nr 3 (2004); Anna Barcz, Realizm ekologiczny. Od ekokrytyki do zookrytyki w literaturze polskiej (Katowice: Wydawnictwo Naukowe Śląsk, 2016); Anita Jarzyna, Post-koiné. Studia o nieantropocentrycznych językach (poetyckich) (Łódź: Wydawnictwo Uniwersytetu Łódzkiego, 2019); Julia Fiedorczuk i Gerardo Baltrán, Ekopoetyka. Ekologiczna obrona poezji (Warszawa: Muzeum Historii Polskiego Ruchu Ludowego, Uniwersytet Warszawski, 2020).

${ }^{61}$ Julia Fiedorczuk, Tlen (Wrocław: Biuro Literackie, 2009), 23.

${ }^{62}$ Zob. Lawrence Buell, The Future of Environmental Criticism: Environmental Crisis and Literary Imagination (Malden-Oxford-Carlton: Blackwell Publishing, 2005).
} 
a sam Buell jest też autorem pojęcia „ekologiczna nieświadomość”63), a więc o ekokrytyczną interpretację wszelkiego rodzaju utworów, zwłaszcza tych, których dyskurs pozostawał ślepy na kwestie środowiskowe. Kiedy więc czytam, dajmy na to, Baśn o wężowym sercu. Słowo wtóre o Jakóbie Szeli Radka Raka, w pierwszej skali jest to dla mnie opowieść o dziwnym splątaniu losów Jakóba Szeli i Wiktoryna Bogusza, w drugiej - narracja o dziewiętnastowiecznych stosunkach pańszczyźnianych, które już niedługo, wraz z uwłaszczeniem chłopów, odejdą do historii, choć pozostawią głęboki ślad na kulturze polskiej. W trzeciej skali natomiast zaczynam zastanawiać się nad szerszym kontekstem: wewnętrzną kolonizacją I Rzeczpospolitej przez szlachtę, półperyferyjnym statusem kultury polskiej w trwającym od XVI wieku kapitalistycznym systemie-świecie, eksportem zbóż i drewna, które karmiły Europę Zachodnią i budowały europejskie statki dokonujące podbojów kolonialnych, wymianą kolumbijską i eksterminacją rdzennej ludności obu Ameryk oraz planetarną unifikacją gatunków roślin i zwierząt, jakie nastąpiły w jej skutek, strukturalnym podobieństwem losu chłopów i czarnoskórych niewolników pracujących na plantacjach obu Ameryk, ideologią „taniej natury” 64 - i tak dalej. Krótko mówiąc: zaczynam sytuować tę opowieść w kontekście kapitałocenu, za który wielu badaczy obwinia dzisiejszy kryzys środowiskowo-klimatyczny.

Czy jest to nadinterpretacja? Oczywiście. Rzecz w tym, że antropocen woła właśnie o środowiskową, klimatyczną, więcej-niż-ludzką, twórczą nadinterpretację w sensie, jaki proponowali np. Jonathan Culler czy Colin Davis. „Zwichnięcie” polega tu na tym, że nie sposób czytać tekstów literackich jedynie na poziomie ich intencjonalności, co w gruncie rzeczy jest już dobrze przerobioną (również przez ekokrytykę $e^{65}$ ) lekcją dekonstrukcji. Propozycja Clarka ma jednak znacznie dalej posunięte implikacje. Jeśli każde pisanie wystawia się na wolną grę znaków, to jest to także argument przeciw naiwnej ekokrytyce pragnącej zmieniać nasze kulturowe przyzwyczajenia i rozwijać „świadomość ekologiczną” - skoro wszyscy aktorzy tego świata mówią, jak przekonuje biosemiotyka ${ }^{66}$, to również ich komunikaty podlegają dyseminacji, nie można ich traktować jako skupionych, sensownych, całościowych informacji. Dlatego np. Morton krytykuje powszechnie stosowaną w ekokrytyce strategię „ekomimesis” polegającą na substancjalnym ujmowaniu natury jako czegoś namacalnego, wszechobecnego, doświadczanego bezpośrednio i niechybnie przez to estetyzowanego ${ }^{67}$, zaś Boes i Marshall postulują wprowadzenie w jej miejsce „ekodiegesis” - pisania nieimitującego „natury”, ale oddającego głos samej planecie i jej aktorom, a także wskazującego na nieuchronny dystans narracyjny przeczący iluzji immersji w świat życia ${ }^{68}$.

${ }^{63}$ Lawrence Buell, Writing for an Endangered World: Literature, Culture, and Environment in the U.S. and Beyond (Cambridge-London: Harvard University Press, 2001), 18-27.

${ }^{64}$ Zob. Raj Patel i Jason W. Moore, „Tania natura”, w O jeden las za daleko. Demokracja, kapitalizm i nieposłuszeństwo ekologiczne w Polsce, red. Przemysław Czapliński, Joanna B. Bednarek i Dawid Gostyński (Warszawa: Książka i Prasa, 2019).

${ }^{65}$ Zob. np. Serpil Oppermann, „Rethinking Ecocriticism in an Ecological Postmodern Framework: Mangled Matter, Meaning, and Agency", w Literature, Ecology, Ethics: Recent Trends in Ecocriticism, red. Timo Müller i Michael Salter (Heidelberg: Universtitatsverlag Winter, 2012), 35-50; Scott Knickerbocker, Ecopoetics: The Language of Nature, the Nature of Language (Boston: University of Massachusetts Press, 2012).

${ }^{66}$ Zob. np. Wendy Wheeler, „The Biosemiotic Turn: Abduction, or, the Nature of Creative Reason in Nature and Culture", w Ecocritical Theory: New European Approaches, red. Axel Goodbody i Kate Rigby (CharlottesvilleLondon: University of Virginia Press, 2011).

${ }^{67}$ Zob. Timothy Morton, Ecology without Nature. Rethinking Ecological Aesthetics (Cambridge-London: Harvard University Press, 2007).

${ }^{68}$ Boes i Marshall, „Writing the Anthropocene: An Introduction”, 64. 
Jeśli jednak Clark zachęca do anachronicznej lektury wszelkich tekstów literackich, to inna badaczka zainteresowana przeorientowaniem pola ekokrytyki, Lynn Keller, skupia się właśnie na utworach poetyckich, które powstały po 2000 roku, gdy termin antropocen został już spopularyzowany przez Paula Crutzena i Eugene’a Stoermera ${ }^{69}$. Autorka książki Recomposing Ecopoetics nazywa je „poezją samoświadomego antropocenu”:

Ukułam frazę „samoświadomy antropocen”, aby zaopatrzyć nas w termin odróżniający się od określenia epoki geologicznej, która być może rozpoczęła się już przed wiekami, i wskazujący na tę bardzo niedawną świadomość. Identyfikuje on okres od wprowadzenia terminu antropocen, odkąd - niezależnie od tego, czy ludzie używają tego słowa, czy nie - istnieje rozległe „rozpoznanie, iż ludzkie działania prowadzą do daleko idących zmian w infrastrukturze podtrzymującej życie na Ziemi"70.

We wstępie do książki Keller, podobnie jak Clark, podkreśla konieczność rozszerzenia zainteresowań ekokrytyki, tak aby nie obejmowała ona jedynie tradycyjnego nature writing czy ekopoetyki, ale także wszelkie teksty „samoświadomego antropocenu” wskazujące na całościowy wpływ człowieka na system planetarny Ziemi. Chodzi tu nie tylko o reprezentacje tego wpływu (skalarne zmiany antropocenu uniemożliwiają takie przedstawienie), ale i o poezję eksperymentalno-awangardową przełamującą granice (ludzkiej) komunikacji. Zgodnie ze słowami Evelyn Reilly celem jest wypracowanie nowej ekopoetyki, która pomagałaby „uświadomić sobie pełne implikacje naszej pozycji jako posługujących się językiem zwierząt w świecie składającym się z wzajemnych zależności. [...] Ekopoetyka musi być kwestią odnajdywania formalnych strategii, które skutkują szerszą zmianą paradygmatu i które faktycznie uczestniczą w zadaniu zadawania kłamu estetycznemu wykorzystywaniu natury jako lustra dla ludzkiego narcyzmu"71.

Keller proponuje więc redefinicję roli ekopoetyki, która powinna nie tyle praktykować ekomimesis (przedstawiać „czystą naturę”), ile właśnie wskazywać na kontaminację, i to w podwójnym sensie tego słowa: 1) powiązanie aktorów ludzkich i nie-ludzkich, nieczystość podziału natura-kultura, 2) całkiem dosłowne zanieczyszczenie: fakt, że ilekroć wdychamy powietrze, wdychamy też znajdujące się w nim pyły zawieszone, ilekroć spożywamy najbardziej nawet „organiczny” pokarm, może on zawierać drobiny mikro- albo wręcz nanoplastiku, ilekroć kąpiemy się w morzu, jest to morze zakwaszone przez absorpcję nadmiaru antropogenicznych gazów cieplarnianych - i tak dalej ${ }^{72}$. W takim ujęciu poeta staje się kimś w rodzaju, jak to ujęła Joan Retallack, „radykalnego epistemologa”73 czy też, jak

\footnotetext{
${ }^{69}$ Paul Crutzen i Eugene Stoermer, „The Anthropocene”, IGBP Global Change Newsletter 41 (2000).

${ }^{70}$ Lynn Keller, Recomposing Ecopoetics: North American Poetry of the Self-Conscious Anthropocene

(Charlottesville-London: Univeristy of Virginia Press, 2017), 1. Keller cytuje jeden z ważniejszych artykułów w debacie o punkcie początkowym antropocenu: Simon L. Lewis i Mark A. Maslin, „Defining the Anthropocene”, Nature 519, nr 7542 (2015): 171-80. Autorzy zaproponowali wbicie „złotego gwoździa” wyznaczającego nową epokę w 1610 roku. O podobnej „epokowej świadomości” zmiany klimatu pisze też Chakrabarty, "The Human Condition in the Anthropocene”.

${ }^{71}$ Evelyn Reilly, „Eco-Noise and the Flux of Lux”, w Eco Language Reader, red. Brenda Iijima (Brooklyn: Nightboat Books, 2010), 261.

${ }^{72} \mathrm{~W}$ podobną stronę zmierza Morton w swym projekcie ciemnej ekologii. Zob. Timothy Morton, Dark Ecology: For a Logic of Future Coexistence (New York: Columbia University Press, 2016).

${ }^{73}$ Joan Retallack, „What Is Experimental Poetry \& Why Do We Need It?”, Jacket 32 (2007), http:// jacketmagazine.com/32/p-retallack.shtml. (dostęp: 11.06.2021)
} 
sam wolałbym go nazwać, radykalnego hermeneuty, z jednej strony wskazującego na konieczność rozszerzania „rozumienia” na aktorów pozaludzkich, z drugiej - podkreślającego aporetyczność tego postulatu.

Skąd bierze się ta aporetyczność? Podobnie jak dla Clarka, fundamentalnym aspektem antropocenu są dla Keller zmiany skalarne: wymieszanie wysoce sprzecznych skal czasowych, przestrzennych, technologicznych, środowiskowych czy wreszcie tych dotyczących ludzkiej sprawczości. Samoświadomość antropocenu wymaga więc myślenia zarówno w znacznie szerszych, jak i w znacznie mniejszych skalach niż te, do których przyzwyczaiła nas ideologia ludzkiego ekscepcjonalizmu. Tym bardziej że - jak zauważa Derek Woods - nie działają jednak jak skala kartograficzna, którą dałoby się powiększać lub pomniejszać z zachowaniem wszelkich proporcji ${ }^{74}$. Niekartograficzny koncept skali, dokładnie na odwrót, wskazuje na fundamentalną nieciągłość - dlatego właśnie skala planetarna oznacza zwichnięcie skali ludzkiej.

Co więcej, okazuje się, że ludzka sprawczość tak naprawdę nie jest ludzka, gdyż stanowi „sumę terraformujących asamblaży, na które składają się ludzie, gatunki nie-ludzkie i technika"75. Wszystko to wywołuje kognitywny i afektywny „dysonans skalarny” - nieprzyjemne napięcie wynikające ze sprzeczności pomiędzy niewielką sprawczością indywidualną a olbrzymim zbiorowym wpływem ludzkości na system Ziemi: „Podczas gdy kolektywnie popadamy z jednych punktów krytycznych w kolejne, spośród których każdy posiada trudne do pojęcia kaskadowe konsekwencje, jednostka czuje się malutka i bezradna"76. Drugą stroną tego medalu jest utrata poczucia jednostkowej odpowiedzialności za kryzys klimatyczny. Przykładowo: im więcej ludzi uczestniczy w zglobalizowanym modelu społeczeństwa konsumpcjonistycznego, tym mniejsza jednostkowa odpowiedzialność, tym jednak większy kumulatywny efekt ich działań.

Keller nie zachęca już zatem do „ekologicznej nadinterpretacji”, ale bada teksty samoświadomego antropocenu - utwory eksperymentalnie wskazujące na uwikłanie aktorów ludzkich i nie-ludzkich w skalarne konsekwencje istnienia hiperobiektów (blisko tego typu twórczości sytuowałyby się utwory Kacpra Bartczaka ${ }^{77}$ ), zawiązujące afektywne wspólnoty ponadgatunkowe (tu warto przywołać poezję Ilony Witkowskiej ${ }^{78}$ ), przekraczające granice ludzkiego języka i dążące do międzygatunkowego „przekładu biosemiotycznego” (w polskim kontekście najbliżej tego rodzaju działalności sytuują się próby Urszuli Zajączkowskiej) czy wreszcie przyjmujące „kosmiczną”, zdehumanizowaną perspektywę bliską Clarkowskiej trzeciej skali (na myśl przychodzą np. tomy Cielenie lodowca Marcina Ostrychacza, Nebula Anny Adamowicz czy Zakłady holenderskie Radosława Jurczaka ${ }^{79}$.

\footnotetext{
${ }^{74}$ Zob. Derek Woods, „Scale Critique for the Anthropocene”, Minnesota Review, nr 83 (2014): 133-42.

${ }^{75}$ Woods, 134.

${ }^{76}$ Keller, Recomposing Ecopoetics: North American Poetry of the Self-Conscious Anthropocene.

${ }^{77 Z o b . ~ n p . ~ J a k u b ~ S k u r t y s, ~ „ P i e s ́ n ́ ~ k o p a l i n ~ i ~ t w o r z y w ~ s z t u c z n y c h ~(w o k o ́ ł ~ « W i e r s z y ~ o r g a n i c z n y c h » ~ K a c p r a ~}$ Bartczaka)", w Ekokrytyka (Poznań: Wydawnictwo WBPiCAK, 2018), 22-36.

${ }^{78}$ Zob. np. Dawid Kujawa, „Od stawania-się-zwierzęciem do stawania-się-molekularnym. Poezja w ujęciu ekozoficznym”, w Ekokrytyka (Poznań: Wydawnictwo WBPiCAK, 2018), 81-91; Monika Glosowitz, „Wspólnoty afektywne. Ilona Witkowska", w Maszynerie afektywne. Literackie strategie emancypacji w najnowszej polskiej poezji kobiet (Warszawa: Wydawnictwo IBL PAN, 2019), 198-223.

${ }^{79}$ Por. też Julia Fiedorczuk, „Poezja samoświadomego antropocenu”, w Prognoza niepogody. Literatura polska w XXI wieku, red. Maciej Jakubowiak i Szymon Kloska (Wołowiec: Czarne, 2020), 81-93 Autorka artykułu przytacza także inne możliwości przełożenia rozważań Keller na kontekst poezji polskiej.
} 
Jednak z nieco innej perspektywy „samoświadomość antropocenu” pozostaje fałszywą świadomością, o ile nie wskazuje na katastrofalną sprawczość systemu kapitalistycznego. Przypomnijmy, że refleksja Derridy na temat zwichnięcia czasu dokonywała się w imię wierności pewnemu dziedzictwu Marksa i, jak się wydaje, dziedzictwo to warte jest podjęcia także ze względu na skalarne efekty antropocenu. Kiedy więc czytam np. poemat Bailout Tomasza Bąka, jest to dla mnie nie tylko opowieść o następstwach kryzysu gospodarczego, który wybuchł w 2008 roku (druga skala Clarka), ale - być może przede wszystkim - krytyka kapitałocenu. Znajduję w tym tekście wystarczająco dużo fragmentów na temat temporalnej nieprzystawalności krótkoterminowych zysków i długoterminowych konsekwencji kapitalistycznego sposobu produkcji, by wskazać, że Bąk pisze m.in. o „rozdarciu metabolicznym” pomiędzy kapitałem a systemem planetarnym, bez którego nie sposób zrozumieć przyczyn kryzysu środowiskowo-klimatycznego ${ }^{80}$.

\section{Antropocen i możliwość innej historii literatury}

Być może najbardziej konfundującym skalarnym efektem antropocenu jest uświadomienie sobie, że wyznaczał on kondycję życia na Ziemi, zanim jeszcze ktokolwiek zdawał sobie z tego sprawę. Jeśli od 2000 roku żyjemy w „samoświadomym antropocenie”, to jego złowieszcze (lub raczej „człowieszcze”, by przywołać udatny neologizm Michała Prankego ${ }^{81}$ ) widmo krążyło nad nami co najmniej od 1945 roku (początek wielkiego przyspieszenia). Przyszłość była tu już od dawna. Derrida nazwał taki stan rzeczy „efektem wizjera”, polegającym na tym, że „nie widzimy tego, kto na nas patrzy”, „rzecz patrzy na nas i widzi, że my nie widzimy jej nawet wtedy, gdy się tutaj znajduje"82.

Czy wobec tego antropocen nie woła o nową, anachroniczną historię literatury? Czy (zgoła zanieczyszczone) światło, jakie rzuca on na nowoczesną konstytucję, ideologię postępu, ruchy emancypacyjne ograniczone jedynie do aktorów ludzkich itp., nie skłania także do przewartościowania dotychczasowych ustaleń historycznoliterackich oraz do środowiskowo-klimatycznej nadinterpretacji potencjalnie każdego tekstu napisanego po 1945 roku? Czy nie należałoby powtórzyć pytania o możliwość innej historii literatury? Zwłaszcza że gdy po raz pierwszy stawiała je Teresa Walas (notabene: w tym samym roku, w którym ukazał się oryginał Widm Marksa Derridy), już ona zauważała, że dzieje „dają się ukształtować jako równoległe i nakładające się na siebie przebiegi zdarzeń o różnej wielkości i różnym stopniu wyrazistości"83.

\footnotetext{
${ }^{80} Z$ Zob. np. John Bellamy Foster, Marx's Ecology (New York: Monthly Review Press, 2000); Jason W. Moore, Capitalism in the Web of Life: Ecology and the Accumulation of Capital (London: Verso, 2015). Także Crutzen, Steffen i McNeill wskazują na fakt, że system Ziemi operuje w zupełnie innych skalach czasowych niż system ekonomiczny (Crutzen, Steffen i McNeill, „The Anthropocene: Are Humans Now Overwhelming the Great Forces of Nature?", 619). Por. też ironiczne stwierdzenie Hamiltona, że kryzys klimatyczny bierze się nie stąd, że rynki działają źle, ale stąd, że działają zbyt dobrze: ich metabolizm jest znacznie szybszy niż metabolizm systemu Ziemi. Clive Hamilton, „Human Destiny in the Anthropocene”, w The Anthropocene and the Global Environmental Crisis: Rethinking Modernity in a New Epoch, red. Clive Hamilton, Christophe Bonneuil i François Gemenne (New York: Routledge, 2015), 35.

${ }^{81}$ Michał Pranke, Rant (Łódź: Dom Literatury w Łodzi, 2018), 30.

${ }^{82}$ Derrida, Widma Marksa. Stan długu, praca żałoby i nowa międzynarodówka, 26.

${ }^{83}$ Teresa Walas, Czy możliwa jest inna historia literatury? (Kraków: Universitas, 1993), 131.
} 
Innymi słowy, chodziłoby o rodzaj postulowanego także przez Josepha Hillisa Millera „czytania anachronicznego", wychodzącego z założenia, że kreatywna anachronia jest immanentnie wpisana w każdy tekst literacki: „zawsze istnieje możliwość, że nowy, nieprzewidziany kontekst retrospektywnie przekształci tekst, nadając mu zmienioną i być może profetyczną moc" ${ }^{84}$. Tak właśnie zdaniem Clarka działają „retrospektywne ironie antropocenu”, wystawiające wszelką ludzką działalność na kontyngencję głębokiej historii geologicznej ${ }^{85}$. I to te retrospektywne ironie skłaniałyby do napisania innej historii literatury po 1945 roku.

${ }^{84}$ Clark, Ecocriticism on the Edge. The Anthropocene as a Threshold Concept, 63. Por. też J. Hillis Miller, „Anachronistic Reading”, Derrida Today 3, nr 1 (2010): 75-91.

${ }^{85}$ Clark, Ecocriticism on the Edge. The Anthropocene as a Threshold Concept, 129. Nawiasem mówiąc, w pewnym sensie nie ma w tym nic szokującego - czyż nie na tym polega nieograniczona semioza Charlesa Sandersa Peirce'a?

\section{Bibliografia}

Allenby, Braden R. i Daniel Sarewitz. The TechnoHuman Condition. Cambridge: MIT Press, 2018.

Baldwin, Andrew. „Postcolonial Futures: Climate, Race, and the Yet-to-Come”. ISLE: Interdisciplinary Studies in Literature and Environment 24, nr 2 (2017): 292-305.

Barcz, Anna. „Przedmioty ekozagłady. Spekulatywna teoria hiperobiektów Timothy'ego Mortona i jej (możliwe) ślady w literaturze". Teksty Drugie, nr 2 (2018): $75-87$.

Realizm ekologiczny. Od ekokrytyki do zookrytyki w literaturze polskiej. Katowice: Wydawnictwo Naukowe Śląsk, 2016.

Bińczyk, Ewa. Epoka człowieka. Retoryka i marazm antropocenu. Warszawa: Wydawnictwo Naukowe PWN, 2018.

Boes, Tobias i Kate Marshall. „Writing the Anthropocene: An Introduction". The Minnesota Review, nr 83 (2014): 60-72.

Buell, Lawrence. The Environmental Imagination: Thoreau, Nature Writing, and the Formation of American Culture. Cambridge-London: Harvard University Press, 1995.

The Future of Environmental Criticism:

Environmental Crisis and Literary Imagination. Malden-Oxford-Carlton: Blackwell

Publishing, 2005.
Writing for an Endangered World:

Literature, Culture, and Environment in the U.S. and Beyond. Cambridge-London: Harvard University Press, 2001.

Chakrabarty, Dipesh. „Klimat historii. Cztery tezy". Przetłumaczone przez Magda Szcześniak. Teksty Drugie, 5 (2014): 168-99.

- - - „The Human Condition in the Anthropocene". The Tanner Lectures in Human Values, 2015.

Clark, Timothy. Ecocriticism on the Edge. The Anthropocene as a Threshold Concept. LondonNew York: Bloomsbury, 2015.

Crutzen, Paul, Will Steffen i John R. McNeill. „The Anthropocene: Are Humans Now Overwhelming the Great Forces of Nature?". Ambio 36, nr 8 (2007): 614-21.

Crutzen, Paul i Eugene Stoermer. „The Anthropocene". IGBP Global Change Newsletter, 41 (2000): 17-18.

Derrida, Jacques. L'Animal que donc je suis. Paris: Galilée, 2006.

Séminaire La bête et le souverain, t. 1. Paris: Galilée, 2008.

Séminaire La bête et le souverain, t. 2.

Paris: Galilée, 2010. 
Widma Marksa. Stan długu, praca żałoby i nowa międzynarodówka. Przełożone przez Tomasz Załuski. Warszawa: Wydawnictwo Naukowe PWN, 2016.

Environmental Humanities: Voices from the Anthropocene. Zredagowane przez Serpil Oppermann i Serenella Iovino. London-New York: Rowman and Littlefield, 2017.

Felstiner, John. Can Poetry Save the Earth? A Field Guide to Nature Poems. New Haven: Yale University Press, 2009.

Fiedorczuk, Julia. „Poezja samoświadomego antropocenu". W Prognoza niepogody. Literatura polska w XXI wieku. Zredagowane przez Maciej Jakubowiak i Szymon Kloska, 81-93. Wołowiec: Czarne, 2020.

Tlen. Wrocław: Biuro Literackie, 2009.

Fiedorczuk, Julia i Gerardo Baltrán. Ekopoetyka. Ekologiczna obrona poezji. Warszawa: Muzeum Historii Polskiego Ruchu Ludowego, Uniwersytet Warszawski, 2020.

Fisher, Mark. Ghosts of My Life: Writings on Depression, Hauntology and Lost Futures. Alresford: Zero Books, 2014.

Foster, John Bellamy. Marx's Ecology. New York: Monthly Review Press, 2000.

Glosowitz, Monika. „Wspólnoty afektywne. Ilona Witkowska”. W Maszynerie afektywne. Literackie strategie emancypacji w najnowszej polskiej poezji kobiet, 198-223. Warszawa: Wydawnictwo IBL PAN, 2019.

Hamilton, Clive. Defiant Earth: The Fate of Humans in the Anthropocene. Crows Nest: Allen\&Unwin, 2017.

\section{- - - „Human Destiny in the}

Anthropocene”. W The Anthropocene and the Global Environmental Crisis: Rethinking Modernity in a New Epoch. Zredagowane przez Clive Hamilton, Christophe Bonneuil i François Gemenne, 32-43. New York: Routledge, 2015.

Hamilton, Clive, Christophe Bonneuil i François Gemenne. „Thinking the Anthropocene". W The Anthropocene and the Global Environmental Crisis: Rethinking Modernity in a New Epoch. Zredagowane przez Clive Hamilton, Christophe Bonneuil i François Gemenne, 1-13. New York: Routledge, 2015.
Haraway, Donna J. „Staying with the Trouble: Anthropocene, Capitalocene, Chthulucene". W Anthropocene or Capitalocene? Nature, History, and the Crisis of Capitalism. Zredagowane przez Jason W. Moore, 34-76. Oakland: PM Press, 2016.

Heidegger, Martin. Die Grundbegriffe der Metaphysik. Welt-Endlichkeit-Einsamkeit. Frankfurt am Main: Vittorio Klostermann, 1983.

Hillis Miller, Joseph. „Anachronistic Reading”. Derrida Today 3, nr 1 (2010): 75-91.

Hiltner, Ken. „General Introduction”. W Ecocriticism. The Essential Reader. Zredagowane przez Ken Hiltner. London-New York: Routledge, 2015.

Jarzyna, Anita. Post-koiné. Studia o nieantropocentrycznych językach (poetyckich). Łódź: Wydawnictwo Uniwersytetu Łódzkiego, 2019.

Keller, Lynn. Recomposing Ecopoetics: North American Poetry of the Self-Conscious Anthropocene. Charlottesville-London: Univeristy of Virginia Press, 2017.

King, Michalea D., Ian M. Howat, Salvatore G. Candela, Myoung J. Noh, Seongsu Jeong, Brice P.Y. Noël, Michiel R. van den Broeke, Bert Wouters i Adelaide Negrete. „Dynamic ice loss from the Greenland Ice Sheet driven by sustained glacier retreat". Communications Earth \& Environment, nr 1 (2020).

Klimatyczne ABC. Zredagowane przez Magdalena Budziszewska, Aleksandra Kardaś i Zbigniew Bohdanowicz. Warszawa: Wydawnictwa Uniwersytetu Warszawskiego, 2021.

Knickerbocker, Scott. Ecopoetics: The Language of Nature, the Nature of Language. Boston: University of Massachusetts Press, 2012.

Kujawa, Dawid. „Od stawania-się-zwierzęciem do stawania-się-molekularnym. Poezja w ujęciu ekozoficznym". W Ekokrytyka. Zredagowane przez Krzysztof Wojciechowski. 81-91. Poznań: Wydawnictwo WBPiCAK, 2018.

Latour, Bruno. „Agency at the time of the Anthropocene". New Literary History 45, nr 1 (2014): 1-18.

Nigdy nie byliśmy nowocześni. Studium $z$ antropologii symetrycznej. Przetłumaczone przez Maciej Gdula. Warszawa: Oficyna Naukowa, 2011. 
Leggewie, Claus i Harald Welzer. Koniec świata, jaki znaliśmy. Klimat, przyszłość i szanse demokracji. Przetłumaczone przez Piotr Buras. Warszawa: Krytyka Polityczna, 2012.

Lewis, Simon L. i Mark A. Maslin. „Defining the Anthropocene". Nature 519, nr 7542 (2015): 171-80.

McBrien, Justin. „Accumulating Extinction: Planetary Catastrophism in the Necrocene". W Anthropocene or Capitalocene? Nature, History, and the Crisis of Capitalism. Zredagowane przez Jason W. Moore, 116-37. Oakland: PM Press, 2016.

Marzec, Andrzej. Widmontologia. Teoria filozoficzna i praktyka artystyczna ponowoczesności. Warszawa: Fundacja Bęc Zmiana, 2015.

Material Ecocriticism. Zredagowane przez Serenella Iovino i Serpil Oppermann. Bloomington: Indiana University Press, 2014.

Merwin, William Stanley i Julia Fiedorczuk. „Już tylko o ogrodach”. Tygodnik Powszechny, 2013. https://www.tygodnikpowszechny.pl/juztylko-o-ogrodach-19688. (dostęp: 11.06.2021)

Momro, Jakub. Widmontologie nowoczesności. Genezy. Warszawa: Wydawnictwo IBL PAN, 2014.

Moore, Jason W. Capitalism in the Web of Life: Ecology and the Accumulation of Capital. London: Verso, 2015.

\footnotetext{
_-_- „Introduction: Anthropocene or Capitalocene? Nature, History, and the Crisis of Capitalism". W Anthropocene or Capitalocene? Nature, History, and the Crisis of Capitalism. Zredagowane przez Jason W. Moore, 1-13. Oakland: PM Press, 2016.

Morton, Timothy. Dark Ecology: For a Logic of Future Coexistence. New York: Columbia University Press, 2016.
}

\section{- Ecology without Nature. Rethinking Ecological Aesthetics. Cambridge-London:} Harvard University Press, 2007.

\footnotetext{
Hyperobjects: Philosophy and Ecology After the End of the World. MinneapolisLondon: University of Minnesota Press, 2013.

Northcott, Michael. „Eschatology in the Anthropocene: From the Chronos of Deep Time to the Kairos of the Age of Humans". W The Anthropocene and the Global
}

Environmental Crisis: Rethinking Modernity in a New Epoch. Zredagowane przez Clive Hamilton, Christophe Bonneuil i François Gemenne, 100-111. London-New York: Routledge, 2015.

Oppermann, Serpil. „Introducing Migrant Ecologies in an (Un)bordered World". ISLE: Interdisciplinary Studies in Literature and Environment 24, nr 2 (2017): 1-14.

-_—. „Rethinking Ecocriticism in an Ecological Postmodern Framework: Mangled Matter, Meaning, and Agency”. W Literature, Ecology, Ethics: Recent Trends in Ecocriticism. Zredagowane przez Timo Müller i Michael Salter, 35-50. Heidelberg: Universtitatsverlag Winter, 2012.

Patel, Raj i Jason W. Moore. „Tania natura”. W O jeden las za daleko. Demokracja, kapitalizm i nieposłuszeństwo ekologiczne w Polsce. Zredagowane przez Przemysław Czapliński, Joanna B. Bednarek i Dawid Gostyński. Warszawa: Książka i Prasa, 2019.

Popkiewicz, Marcin i Szymon Malinowski. „Rozpad lądolodu Antarktydy Zachodniej nieunikniony”. Nauka o klimacie, 2015. https://naukaoklimacie.pl/aktualnosci/ rozpad-ladolodu-antarktydy-zachodniejnieunikniony-77.

Pranke, Michał. Rant. Łódź: Dom Literatury w Łodzi, 2018.

Reilly, Evelyn. Apocalypso. New York: Roof Books, 2012.

\footnotetext{
- - _. „Eco-Noise and the Flux of Lux”. W Eco Language Reader. Zredagowane przez Brenda Iijima, 255-74. Brooklyn: Nightboat Books, 2010.
}

Retallack, Joan. „What Is Experimental Poetry \& Why Do We Need It?” Jacket 32 (2007). http:// jacketmagazine.com/32/p-retallack.shtml. (dostęp: 11.06.2021)

Rigby, Kate. „Earth, World, Text: On the (Im) possibility of Ecopoiesis". New Literary History 35, nr 3 (2004): 427-42.

\footnotetext{
-_- . „Ecocriticism”. W Introducing Criticism at the 21st Century. Zredagowane przez Julian Wolfreys, 151-78. Edinburgh: Edinburgh University Press, 2002.

Rockström, Johan, Will Steffen, Kevin Noone, Åsa Persson, F. Stuart Chapin, Eric Lambin, Timothy M. Lenton i in. „Planetary
} 
Boundaries: Exploring the Safe Operating Space for Humanity". Ecology and Society 14, nr 2 (2009): 472-75.

Skurtys, Jakub. „Pieśń kopalin i tworzyw sztucznych (wokół «Wierszy organicznych» Kacpra Bartczaka)". W Ekokrytyka. Zredagowane przez Krzysztof Wojciechowski, 22-36. Poznań: Wydawnictwo WBPiCAK, 2018.

Steffen, Will, Wendy Broadgate, Lisa Deutsch, Owen Gaffney i Cornelia Ludwig. „The Trajectory of the Anthropocene: The Great Acceleration". The Anthropocene Review 2, nr 1 (2015): 81-98.

Ubertowska, Aleksandra. „«Mówić w imieniu biotycznej wspólnoty». Anatomie i teorie tekstu środowiskowego". Teksty Drugie, nr 2 (2018): 17-40.

Walas, Teresa. Czy możliwa jest inna historia literatury? Kraków: Universitas, 1993.
Wallerstein, Immanuel. Koniec świata jaki znamy. Przetłumaczone przez Michał Bilewicz, Adam W. Jelonek i Krzysztof Tyszka. Warszawa: Wydawnictwo Scholar, 2004.

Wheeler, Wendy. „The Biosemiotic Turn: Abduction, or, the Nature of Creative Reason in Nature and Culture". W Ecocritical Theory: New European Approaches. Zredagowane przez Axel Goodbody i Kate Rigby, 270-82. Charlottesville-London: University of Virginia Press, 2011.

Widma Derridy. Zredagowane przez Agata Bielik-Robson i Piotr Sadzik. Warszawa: Wydawnictwo IBL PAN, 2018.

Woods, Derek. „Scale Critique for the Anthropocene". Minnesota Review, nr 83 (2014): 133-42.

„Working Group on the «Anthropocene»”, b.d. http://quaternary.stratigraphy.org/workinggroups/anthropocene/. (dostęp: 11.06.2021). 


\title{
SŁOWA KLUCZOWE:
}

\author{
ekokrytyka
}

a n tropocen

\section{ABSTRAKT:}

Pierwsza część artykułu podejmuje teoretyczny namysł nad antropocenem jako epoką, w której nastąpiło radykalne wymieszanie czasu ludzkiego i geologicznego. W części tej przedstawione są wglądy formułowane $\mathrm{w}$ obrębie dyskursu antropocenu, a także ustalenia klimatologii. Skłaniają one do wypracowania widmontologii antropocenu jako epoki, w której „czas wypadł z ram". Druga część artykułu przekłada ustalenia teoretyczne na praktykę literaturoznawczą (zwłaszcza ekokrytyczną). Autor rekonstruuje propozycje uprawiania ekokrytyki w czasach antropocenu sformułowane przez Timothy'ego Clarka oraz Lynn Keller i podejmuje wstępne próby przełożenia ich na kontekst literatury polskiej. 
teorie | Patryk Szaj, Czas, który wypadł z ram...

$w$ i d $m$ o n t o lo gia

\section{Nota O AUTORze:}

Patryk Szaj - ur. w 1989 roku, doktor nauk humanistycznych, literaturoznawca. Pracownik Uniwersytetu Pedagogicznego im. KEN w Krakowie. Interesuje się humanistyką środowiskową, dyskursem antropocenu, związkami między literaturą a filozofią. Autor książek Wierność trudności. Hermeneutyka radykalna Johna D. Caputo a poezja Aleksandra Wata, Tadeusza Różewicza i Stanisława Barańczaka (2019) oraz Od modernizmu do antropocenu. Szkice z hermeneutyki dekonstrukcyjnej (2021, w druku). Redaktor prowadzący serii wydawniczej Humanistyka Środowiskowa (Wydawnictwo WBPiCAK w Poznaniu). Stały współpracownik redakcji dwutygodnika kulturalnego „artPapier” oraz „CzasKultury.pl”. 